\title{
NEKI ASPEKTI PONAŠANJA DJECE RAZVEDENIH RODITELJA - ZAPAŽANJA UČITELJA
}

Apstrakt: S obzirom na učestalost razvoda brakova na čitavom prostoru Europske unije, pa i šire, cilj istraživanja bio je ispitati neke uočene promjene u ponašanju djece razvedenih roditelja te važnost uloge učitelja razredne nastave $u$ procesu prilagodbe djeteta na nastalu obiteljsku situaciju. Istraživanje je provedeno na uzorku učitelja razredne nastave iz raznih dijelova Hrvatske (Primorsko-goranska županija, Brodsko-posavska županija, Koprivničko-križevačka županija, Grad Zagreb). Podaci su se prikupljali uz pomoć anketnog upitnika. Rezultati zapažanja učitelja su pokazali kako razvod roditelja nije uzrokovao promjene u eksternaliziranim ponašanjima i školskom uspjehu djece, ali su zapažene promjene u dijelu emocionalnih reakcija (strah), internaliziranih ponašanja (plašljivost) te odnosa s drugim osobama (povlačenje u sebe). Osim toga, varijable dob, spol, prisutnost nasilja $\mathrm{u}$ obitelji za vrijeme i/ili nakon razvoda, konfliktni razvod, održavanje redovitih kontakata $\mathrm{s}$ roditeljem $\mathrm{s}$ kojim dijete ne živi te kvaliteta suradnje učitelja i roditelja, pokazali su se statistički značajnim. Uspostavljanje veze jednog roditelja (s kojim dijete živi) s novim partnerom nije se pokazalo značajnim prediktorom promjena $\mathrm{u}$ nekim aspektima ponašanja djece. Rezultati istraživanja mogu predstavljati solidnu osnovu za daljnje razvijanje strukturiranih protokola u praćenju razvoja ponašanja i napredovanja djece u njihovoj ranijoj razvojnoj dobi kao jednom od značajnih perioda u životu svakog čovjeka.

Ključne riječi: roditelji, razvod braka, ponašanje djece, osnaživanje obitelji

\section{UVOD I TEORIJSKE OSNOVE ISTRAŽIVANJA}

Razvod braka je, prema recentnim istraživanjima, drugi najstresniji događaj u djetetovu životu nakon smrti roditelja (Bujišić, 2005, Čavarović-

\footnotetext{
*Jasminka Zloković, jzlokovic@ffri.hr
} 
Gabor, 2008). Razvod braka predstavlja visoko rizičnu situaciju u kojoj dolazi do naglih promjena obiteljskog funkcioniranja koje je za dijete predstavljalo „sigurnost“ (Rodrigez, 2007, Čavarović-Gabor, 2008). Dijete se, kod razvoda, najčešće suočava s brojnim promjenama: odvajanje od jednog roditelja, modifikacija kućnih pravila, promjene u financijskom statusu, (ne)prilagodba životnom stilu jednoroditeljske obitelji i dr. (Grozdanić, 2000, Amato i Sobolewski, 2001, Osmak- Franjić, 2007). Utjecaji razvoda roditelja na djecu kreću se od blagih do ozbiljnih, od naizgled malenih do vidljivo značajnih te od kratkoročnih do dugoročnih (Smerić Pecigoš, 2007, Fagan i Churchill, 2012) eksternalnih i(li) internalnih promjena u ponašanju. Reakcije (posljedice) djece na razvod roditelja mogu se podijeliti u tri skupine: inicijalne, kratkoročne i dugoročne (Čudina Obradović i Obradović, 2006).

„Kod inicijalne reakcije razumijevamo prvu reakciju djece na vijest da im se roditelji razvode“ (Čudina Obradović i Obradović, 2006: 583), što je kod većine djece šok. Djeca uglavnom emocionalno ne prihvaćaju razvod braka njihovih roditelja (Čudina Obradović i Obradović, 2006, OsmakFranjić, 2010, Hajnić, 2014). Emocionalne reakcije djece koje se najčešće spominju su: tuga, ljutnja, usamljenost, depresija, anksioznost, briga, nezadovoljstvo životom, loše samopouzdanje i vjera u sebe, strah, čežnja, odbijanje, konflikt lojalnosti i krivnja (Osmak-Franjić, 2007, Fagan i Churchill, 2012). Kod djece se javljaju i zbunjenost, nada, a ponekad i olakšanje posebno u situacijama kada djeca prisustvuju svađama roditelja ili bilo koje druge vrste nasilja.

Smatra se da veliki broj djece uspješno savlada krizno obiteljsko razdoblje, međutim činjenica je da neka djeca doživljavaju emocionalne 
teškoće veće od uobičajene uznemirenosti i tuge, a posljedice razvoda prate ih i u odrasloj dobi“ (Laklija i sur, 2005, Profaca, 2010). Konflikti roditelja i razvod braka prema nekim istraživanima povezani su s povlačenjem, depresijom, smanjenom socijalnom kompetencijom i većom agresivnošću, zdravstvenim problemima te lošijim školskim ocjenama za djecu školske dobi (Katz i Gottman, 1995, prema Brajša-Žganec, 2003). Prema McIntosh (2003) uočene poteškoće kod djece razvedenih roditelja su: socijalne, ekonomske i zdravstvene teškoće, češća pripadnost skupinama rizičnog ponašanja, češća zlouporaba sredstava ovisnosti, češća potreba za psihološkim tretmanom, češće odustajanje od škole (Profaca, 2010). Gottman je provodio istraživanja s odraslima koji su doživjeli razvod roditelja dok su bili djeca. Rezultati su pokazali kako su bili puno više pod stresom nego druga djeca koja nisu doživjela razvod roditelja, bili su manje zadovoljni sa svojom obitelji i prijateljima, proživljavali su više neugodnih životnih događaja i birali loše strategije za suočavanje s njima (Gottman, 1998, prema Brajša-Žganec, 2003). Razvod roditelja povezan je i s nižim socioekonomskim statusom u odrasloj dobi (češće odustaju od srednje škole, rjeđe pohađaju fakultet), a negativno utječe i na kvalitetu i stabilnost uspostave intimnih veza u odrasloj dobi (Amato i Sobolewski, 2001). Prema istraživanju Fagan i Churchill (2012) odobravanje preuranjenih predbračnih intimnih odnosa značajno je povećana kod djece razvedenih roditelja (Smerić Pecigoš, 2007, Fagan i Churchill, 2012). Psihološka dobrobit djeteta Amato i Sobolewski smatraju da opada činom razvoda roditelja (2001). Razvod roditelja pripada u skupinu izraženih traumatskih faktora koji povećava rizik od pojave psihičkih problema kod djece. Tako Krnić (2010) iznosi podatak da 20 do $25 \%$ djece razvedenih roditelja ima psihičkih poteškoća, što je gotovo duplo više nego kod djece iz cjelovitih obitelji. 
Autorice ovog rada problemu prilaze s holističke perspektive i smatraju kako, osim što valja uzeti u obzir rezultate dosadašnjih istraživanja, svakako valja pristupiti i s kritičkog aspekta, posebice jer smatramo da je svaka osoba individua za sebe i da sama činjenica razvoda braka za dijete ne mora nužno značiti i neželjene posljedice po njegovo zdravlje i ponašanje. Rezultati istraživanja koje u radu iznosimo otvaraju i niz pitanja u kontekstu rasprava tipa pro-contra o razvodu roditelja.

\section{METODOLOGIJA ISTRAŽIVANJA}

Razvod braka na području EU i šire predstavlja jedan od obiteljskih i socijalnih problema s tendencijom porasta. Veliki broj razvoda (predrazvod, razvod i postrazvod) su visokokonfliktni, što posebno predstavlja problem ukoliko su prisutna djeca. Posljedice roditeljskih konflikata kod djece manifestiraju se na različite načine, a neke od njih su prisutne i tijekom čitavog života. Za vrijeme ranijeg razvojnog perioda i polaskom djeteta $\mathrm{u}$ školu učitelji su u posebnoj prilici zapažati ponašanje i promjene u ponašanju djeteta.

Predmet ovog istraživanja je ispitivanje nekih aspekta ponašanja djece razvedenih roditelja koji bi mogli upućivati na promjene koje je potrebno što ranije uočiti a djetetu pružiti pravovremenu stručnu i obiteljsku podršku. Sukladno tome, glavni opći cilj je ispitati zapažanja učitelja razredne nastave o promjenama ponašanja djece nakon razvoda njihovih roditelja te ispitati percipciju vlastite uloge učitelja u procesu prilagodbe djece na činjenicu roditeljskog razvoda. Iz cilja su proizašli zadaci istraživanja: ispitati mišljenja učitelja o pozitivnim/negativnim posljedicama razvoda braka roditelja na djecu, o uočenim promjenama $\mathrm{u}$ emocionalnim reakcijama djece nakon 
razvoda njihovih roditelja te o promjenama $\mathrm{u}$ eksternaliziranim i (li) internaliziranim ponašanjima djece nakon razvoda roditelja. Također, kao neke od zadataka postavili smo i ispitivanje mišljenja učitelja o uočenim promjenama u školskom uspjehu djece, o promjenama u odnosima djece $\mathrm{s}$ drugim vršnjacima ili odraslim osobama te mišljenje učitelja o njihovoj osobnoj ulozi u prilagodbi djece na razvod roditelja.

Istraživanje se provodilo na namjernom uzorku od 35 učitelja razredne nastave s područja Republike Hrvatske. S područja Primorskogoranske županije u istraživanju je sudjelovalo 20 učitelja iz osam osnovnih škola, iz Brodsko-posavske 2 učitelja iz jedne škole, iz Koprivničkokriževačke 2 učitelja iz dvije škole te iz Grada Zagreba 9 učitelja iz dvije osnovne škole.

Rezultate smo prikupili uz pomoć posebno kreiranog anketnog upitnika koji se sastojao od pitanja zatvorenog i otvorenog tipa. Kod dijela pitanja koristili smo se Likertovom ljestvicom od 1 do 5 (pri čemu 1 znači ' $u$ potpunosti se ne slažem s tvrdnjom', a 5 označava 'u potpunosti se slažem'). U interpretaciji rezultata koristili smo se kvantitativnom i kvalitativnom metodologijom.

\section{REZULTATI ISTRAŽIVANJA I DISKUSIJA}

S obzirom na obim istraživanja i prikupljenih rezultata u ovome radu možemo izdvojiti tek neke od njih. Uz pomoć deskriptivne statistike izdvajamo prosječne vrijednosti odgovora učitelja na različito postavljene tvrdnje vezane za uočene pozitivne i(li)negativne posljedice razvoda roditelja na razvoj djeteta. Za odgovor na ovo pitanje koristila se i Likertova ljestvica od 1 do 5 (pri čemu 1 znači 'u potpunosti se ne slažem s tvrdnjom', a 5 
označava 'u potpunosti se slažem'). Odgovori ispitanika na tvrdnju Primjećujem pozitivne posljedice razvoda roditelja na djetetov razvoj iznosi tek vrijednost 2,11. Niti jedan ispitanik nije izrazio potpuno slaganje $s$ tvrdnjom, dok se za potpuno neslaganje odlučilo njih 24,3\%. Valja napomenuti kako je najviše onih koji se ne slažu s tom tvrdnjom (40,5\%). Odgovori na tvrdnju Primjećujem negativne posljedice razvoda roditelja na djetetov razvoj iznose prosječnu vrijednost 3,51. S ovom se tvrdnjom u potpunosti slaže 18,9\% ispitanika, a potpuno neslaganje s njom je izrazilo 5,4\% ispitanika. Važno je napomenuti kako je najviše onih koji se slažu, njih 32,4\%. Možemo pokušati zaključiti kako veliki broj ispitanika uočava neke negativne posljedice razvoda braka na djecu. Naime, slaganje s tvrdnjom ('slažem se' i 'u potpunosti se slažem') o uočavanju negativnih posljedica razvoda braka na djecu je zabeleženo kod 51,3\% ispitanika. Suprotno tome, slaganje $s$ tvrdnjom o pozitivnim posljedicama u ponašanju djece izrazilo je tek $5,4 \%$ ispitanika.

Kada se ispitanike pitalo o nekim uočenim posljedicama razvoda braka roditelja na emocionalno reagiranje djece, češće su opisivali negativne posljedice. Iako niti jedan odgovor ne zanemarujemo, samo četiri ispitanika je opisalo pozitivne posljedice, poput kvalitetnog odnosa s vršnjacima i učiteljima, emocionalne uravnoteženosti i otvorenog izražavanja emocija. S druge strane, navedene su brojne negativne posljedice razvoda roditelja na emocionalno reagiranje djeteta, poput izražene ljutnje i inata, teže percepcije tuđih osjećaja i izražene prestrašenosti. Što se tiče statistički značajne razlike u emocionalnom reagiranju djece prije i nakon razvoda njihovih roditelja, značajnost je dokazana s obzirom na pojavu straha kod djece $(\mathrm{t}(34)=3,095$, $\mathrm{p}<0,05)$. Nakon razvoda roditelja djeca su, prema mišljenju ispitanika, 
pokazivala manje straha $(M=2,63, s=1,087)$ negoli prije $(M=2,06, s=0,802)$. Moguće logično objašnjenje ovakvih rezultata je prisutnost svađa i nasilja $u$ obitelji pre razvoda, pa je dijete osjećalo strah, sve dok jedan roditelj nije otišao, a svađe i nasilje nisu prestali (?).

Ispitanici su češće navodili negativne nego pozitivne posljedice razvoda braka roditelja na eksternalizirana ponašanja djece. Ne postoji statistički značajna razlika niti u jednom dijelu eksternaliziranih ponašanja djece prije i nakon razvoda njihovih roditelja. Stoga valja napomenuti kako prethodna istraživanja dokazuju puno intenzivnije negativne posljedice razvoda roditelja na eksternalizirana ponašanja djece.

Prema odgovorima ispitanika, pozitivnih posljedica na internalizirana ponašanja djece nema, dok su negativne prisutne. Djeca se, naime, teško odvajaju od roditelja te su zabrinuta. Ovakvi odgovori su dijelom i očekivani budući da su djeca prije razvoda navikla na život s oba roditelja, a nakon razvoda su ostali živjeti samo s jednim, zbog čega se kod njih javlja osjećaj napuštenosti i briga da ih i drugi roditelj ne napusti. Sličnu interpretaciju nalazimo i kod Bujišić (2005). Rezultati istraživanja su, suprotno nekima dosadašnjim, pokazali kako postoje i neke pozitivne posljedice razvoda braka roditelja na školski uspjeh djeteta i njegovo ponašanje za vrijeme boravka u školi i s vršnjacima. Ispitanici su naglašavali kako je dijete zainteresirano za nastavu i redovito izvršava zadatke. Naši rezultati dijelom su u suprotnosti s nekim dosadašnjim recentnim istraživanjima koja pokazuju kako školski uspjeh djeteta nakon razvoda roditelja opada, a ponašanje na nastavi se pogoršava (Lee, 2000, Brajša- Žganec, 2003, Fagan i Churchill, 2012, Amato, 2014). 
Slična neslaganja s recentnim istraživanima se odnose i na rezultate koji pokazuju kako su naši ispitanici češće uočavali pozitivne nego negativne posljedice razvoda braka roditelja na odnose djeteta s drugim osobama. Neke pozitivne posljedice koje su navodili jesu: suradnja $\mathrm{s}$ drugima $\mathrm{u}$ učenju, suradnja s drugima u igri, otvorenost i suradnja s učiteljem. U literaturi je pak većinom uvriježeno mišljenje kako djeca razvedenih roditelja imaju lošije socijalne vještine od onih čiji roditelji nisu razvedeni (Lee, 2000, Fagan i Churchill, 2012, Amato, 2014), s čime se naši rezultati ne poklapaju. Naposljetku je utvrđeno da postoji statistički značajna razlika u povlačenju djece od vršnjaka u situacijama međusobnog druženja prije i nakon razvoda njihovih roditelja $(\mathrm{t}(33)=3,118, \mathrm{p}<0,05)$. Prije razvoda djeca su se statistički značajno više povlačila od vršnjaka u situacijama međusobnog druženja $(\mathrm{M}=2,29, \mathrm{~s}=1,268)$ nego nakon razvoda $(\mathrm{M}=1,68, \mathrm{~s}=0,727)$. Kada ovakve rezultate usporedimo s prethodnim istraživanjima, dolazimo do suprotnog zaključka.

U drugom su se dijelu našeg istraživanja ispitivale promjene u nekim aspektima ponašanja djece razvedenih roditelja s obzirom na dob i spol djeteta, prisutnost nasilja u obitelji za vrijeme i/ili nakon razvoda roditelja, konfliktnu prirodu razvoda ili roditelja s kojim dijete živi, postojanje novog partnera roditelja s kojim dijete živi, održavanje redovitih kontakata $\mathrm{s}$ roditeljem s kojim dijete ne živi te kvalitetu suradnje učitelja i roditelja.

Rezultati su pokazali da se skupine međusobno statistički značajno ne razlikuju $\mathrm{u}$ emocionalnom reagiranju, internaliziranim ponašanjima, školskom uspjehu i ponašanju na nastavi te odnosima s drugima s obzirom na dob. Statistički značajna razlika je dokazana samo u dijelu eksternaliziranih ponašanja. S obzirom na dob sedmogodišnjaci, osmogodišnjaci, 
devetogodišnjaci, desetogodišnjaci se statistički značajno razlikuju u samoozljeđivanju $(\mathrm{F}(3,30)=4,951, \mathrm{P}<0,05)$, fizičkoj $(\mathrm{F}(3,31)=3,446, \mathrm{p}<0,05)$ i psihičkoj agresiji $(\mathrm{F}(3,31)=5,279, \mathrm{p}<0,05)$ prema vršnjacima te uništavanju imovine $(\mathrm{F}(3,31)=9,75, \mathrm{p}<0,05)$. Sedmogodišnjaci su više fizički agresivni prema vršnjacima $(M=3,667, s=0,649)$ nego devetogodišnjaci $(M=1,385$, $\mathrm{s}=0,312)$, a također i skloniji samoozljeđivanju ( $M=3,00, \mathrm{~s}=0,426 ; \mathrm{M}=1,333$, $\mathrm{s}=0,301, \mathrm{M}=1,231, \mathrm{~s}=0,204, \mathrm{M}=1,333, \mathrm{~s}=0,213)$, psihičkoj agresiji prema vršnjacima $(M=3,67, s=2,309 ; M=1,71, s=0,756, M=1,38, s=0,506, M=1,50$, $\mathrm{s}=0,905)$ te uništavanju imovine od ostalih skupina $(\mathrm{M}=3,33, \mathrm{~s}=2,082$; $\mathrm{M}=1,14, \quad \mathrm{~s}=0,378, \mathrm{M}=1,15, \mathrm{~s}=0,376, \mathrm{M}=1,25, \mathrm{~s}=0,452)$. Istraživanje Strohschein (2005) je pokazalo kako ne postoje razlike posljedica razvoda roditelja s obzirom na dob djeteta, a ista autorica navodi kako su prethodna istraživanja pokazala da su efekti razvoda snažniji na mlađu djecu, a starija djeca pokazuju više asocijalnih ponašanja (Strohschein, 2005). Rezultati su našeg istraživanja, nadalje, pokazali kako ne postoji statistički značajna razlika u emocionalnom reagiranju djece razvedenih roditelja, njihovim internaliziranim ponašanjima, školskom uspjehu i ponašanju na nastavi te njihovim odnosima s drugima između muške i ženske djece razvedenih roditelja. Statistički značajna razlika dokazana je jedino u dijelu eksternaliziranih ponašanja $(\mathrm{t}(32)=1,776, \quad \mathrm{p}<0,05 ; \mathrm{t}(33)=1,663, \quad \mathrm{p}<0,05$; $\mathrm{t}(33)=1,682, \quad \mathrm{p}<0,05, \mathrm{t}(33)=1,682, \mathrm{p}<0,05)$. Dječaci su skloniji fizičkoj $(\mathrm{M}=1,40, \mathrm{~s}=0,632 ; \mathrm{M}=1,11, \mathrm{~s}=0,315)$ i psihičkoj agresiji prema učitelju/ici $(\mathrm{M}=1,38, \mathrm{~s}=0,619 ; \mathrm{M}=1,11, \mathrm{~s}=0,315)$, češće pokazuju seksualna ponašanja neprimjerena dobi $(M=1,25, s=0,447 ; M=1,05, s=0,229)$ te češće bježe iz škole $(M=1,25, s=0,447 ; M=1,05, s=0,229)$ nego ženska djeca. Ranija istraživanja nisu pokazala ovakav već suprotan smjer (više u: Amato i Sobolewski, 2001). Rezultati našeg istraživanja su također pokazali da se 
djeca u čijoj je obitelji za vrijeme i/ili nakon razvoda bilo prisutno nasilje, djeca u čijoj obitelji ono nije bilo prisutno i djeca kod kojih učitelji nisu upućeni u prisutnost nasilja u obitelji međusobno statistički značajno ne razlikuju u internaliziranim ponašanjima, školskom uspjehu i ponašanju na nastavi. Statistički značajna razlika je dokazana u dijelu emocionalnih reakcija (otvoreno izražavanje emocija $-\mathrm{F}(2,31)=4,256$, $\mathrm{p}<0,05$; izražavanje emocija destruktivnim ponašanjem - $\mathrm{F}(2,32)=5,000, \quad \mathrm{p}<0,05)$ ), eksternaliziranih ponašanja (fizička agresija prema vršnjacima $F(2,32)=6,796, p<0,05$; psihička agresija prema vršnjacima $-(F(2,32)=8,284$, $\mathrm{p}<0,05$; postojanje rizika za razvoj poremećaja u ponašanju $-(\mathrm{F}(2,31)=3,394$, $\mathrm{p}<0,05)$ ) i odnosa $\mathrm{s}$ drugima (suradnja $\mathrm{s}$ vršnjacima na nastavi $\mathrm{F}(2,31)=4,456, \mathrm{p}<0,05)$. Djeca u čijoj obitelji nije bilo prisutno nasilje otvorenije izražavaju emocije $(M=4,15, S=0,689)$ te više surađuju $s$ vršnjacima na nastavi $(\mathrm{M}=4,38, \mathrm{~s}=0,506)$ od djece u čiju situaciju u obitelji vezanu za nasilje učitelji nisu upućeni $(M=3,18, s=1,286 ; M=3,59, s=0,939)$. Dokazano je također da djeca kod koje je bilo prisutno nasilje u obitelji češće izražavaju emocije destruktivnim ponašanjima $(M=3,50, s=1,291)$, češće su fizički $(M=3,25, s=1,708)$ i psihički agresivna $(M=3,25, s=1,500)$ prema vršnjacima te kod njih postoji veći rizik za razvoj poremećaja u ponašanju $(\mathrm{M}=3,25, \mathrm{~s}=1,708)$ nego kod djece u čijoj obitelji nije bilo prisutno nasilje $(M=1,54, s=0,660 ; M=1,08 ; s=0,277 ; M=1,72, s=1,018 ; M=1,54, s=0,776)$. Ovakvi rezultati mogu se protumačiti time da djeca koja svjedoče ili su izložena nasilju u obitelji takav način rješavanja sukoba prihvaćaju kao normalan, a takva ponašanja unose u kasnije odnose u svom životu. Neuropsihologijska istraživanja pokušavaju dokazati da izloženost djeteta nasilju u obitelji uzrokuje emocionalne probleme i probleme u ponašanju, 
lošiji uspjeh u školi i lošije kognitivno funkcioniranje (Kocijan-Hercigonja i Hercigonja-Novković, 2009).

Prema našim rezultatima djeca koja su proživjela visoko konfliktan razvod roditelja pokazuju više ljutnje i bijesa $(M=3,09, s=1,136)$ od djece koja ga nisu proživjela kao takvog $(\mathrm{M}=1,73, \mathrm{~s}=0,467)$ te se češće obraćaju učitelju oko problema vezanih za gradivo $(M=4,36, s=0,674)$ od one djece $u$ čijoj situaciji učitelji nisu upućeni u konfliktnu prirodu razvoda $(\mathrm{M}=3,50$, $\mathrm{s}=1,000)$. Naposljetku, djeca u čijoj situaciji učitelji nisu upućeni u konfliktnu prirodu razvoda se češće žale na bolove $\mathrm{i} / \mathrm{ili}$ mučninu $(\mathrm{M}=2,54$, $\mathrm{s}=1,330)$ od djece koja su proživjela visoko konfliktan razvod $(\mathrm{M}=1,45$, $\mathrm{s}=0,522)$. Uspoređujući naše rezultate $\mathrm{s}$ dosadašnjom literaturom i ranije provedenim istraživanjima uočavamo mnoge suprotnosti. Ovo se odnosi i na podatak kako se djeca koja su proživjela visoko konfliktan razvod roditelja ne razlikuju od djece koja ga nisu proživjela niti u jednom aspektu ponašanja koji se istraživao.

S obzirom na rezultate ispitivanja koje smo dobili u svezi varijabli susreta i kontakta s roditeljem s kojim dijete ne živi možemo zaključiti kako su kod djece koja ne održavaju redovite kontakte s roditeljem prisutnije negativne emocije $(M=5,00, s=0,000)$, ona su češće fizički $(M=3,33$, $\mathrm{s}=2,082)$ i psihički agresivna prema vršnjacima $(\mathrm{M}=3,33, \mathrm{~S}=2,082)$ te su kod njih prisutnije pozitivne emocije $(\mathrm{M}=4,33, \mathrm{~s}=1,155)$ nego kod djece $\mathrm{u}$ čijoj situaciji učitelji nisu sigurni u održavanje redovitih kontakata $\mathrm{s}$ drugim roditeljem $(M=2,68, s=1,090) ; M=1,54, s=1,036 ; M=1,54, s=0,881, M=2,50$, $\mathrm{s}=1,000)$. Kod djece, naposljetku, koja održavaju redovite kontakte s drugim roditeljem češće prevladavaju pozitivne emocije $(\mathrm{M}=3,79, \mathrm{~s}=0,876)$ nego kod djece u čijoj situaciji učitelji nisu sigurni u održavanje redovitih kontakata s 
drugim roditeljem $(M=2,50, s=1,000)$. I prema znanstveno-stručnoj literaturi odsutnost jednog roditelja u brizi i odgoju djece može biti uzrok teškoćama kod djece nakon razvoda njihovih roditelja (Amato i Keith, 1991, prema Čudina Obradović i Obradović, 2006). Različita istraživanja su pokazala kako djeca razvedenih roditelja imaju potrebu provoditi vrijeme s oba roditelja, a zajedničko skrbništvo rezultira najboljom prilagodbom djeteta na razvod njegovih roditelja. Također, djeca koja ne održavaju odnos $\mathrm{s}$ roditeljem s kojim ne žive su u većem psihološkom riziku od onih koji ga održavaju (Kruk, 2008). Ovo se istraživanje dijelom slaže s navedenim teorijskim i istraživačkim zaključcima. Naime, dokazano je kako djeca koja ne održavaju redovite kontakte s roditeljem s kojim ne žive pokazuju statistički značajno više negativnih emocija od djece koja redovito kontaktiraju s drugim roditeljem te su više fizički i psihički agresivna prema vršnjacima, a kod djece koja održavaju redovite kontakte s roditeljem s kojim ne žive prevladavaju pozitivne emocije. Ovakvi rezultati upućuju na važnost održavanja odnosa s oba roditelja, bez obzira na razvod roditelja.

Rezultati su, naposljetku, pokazali da se djeca čiji roditelji ostvaruju kvalitetnu suradnju s učiteljem i oni čija je suradnja osrednje kvalitetna međusobno statistički značajno ne razlikuju u internaliziranim ponašanjima te odnosima s drugima. Statistički značajna razlika je dokazana u dijelu emocionalnih reakcija, eksternaliziranih ponašanja i školskog uspjeha i ponašanja na nastavi $(\mathrm{F}(2,32=3,696, \quad \mathrm{p}<0,05 ; \mathrm{F}(1,33)=4,255, \quad \mathrm{p}<0,05$; $\mathrm{F}(1,32)=7,373, \mathrm{p}<0,05 ; \quad \mathrm{F}(1,33)=4,504, \mathrm{p}<0,05 ; \quad \mathrm{F}(1,33)=5,989, \quad \mathrm{p}<0,05$; $\mathrm{F}(1,33)=6,307, \mathrm{p}<0,05 ; \mathrm{F}(1,33)=4,427, \mathrm{p}<0,05 ; \mathrm{F}(1,31)=5,491, \mathrm{p}<0,05)$. Naime, djeca čiji roditelji ostvaruju osrednje kvalitetnu suradnju s učiteljima pokazuju više negativnih emocija $(M=3,50, s=1,092)$, ljutnje i bijesa 
$(\mathrm{M}=3,15, \mathrm{~s}=1,281)$, češće su nezadovoljni životom $(\mathrm{M}=2,93, \mathrm{~s}=1,269)$, češće izražavaju emocije plakanjem $(\mathrm{M}=2,86, \mathrm{~s}=1,562)$ i destruktivnim ponašanjima $(M=2,64, s=1,216)$, češće su fizički agresivna prema vršnjacima $(\mathrm{M}=2,29, \mathrm{~s}=1,437)$ te češće ometaju nastavu $(\mathrm{M}=2,85, \mathrm{~s}=1,519)$ od djece čiji roditelji ostvaruju kvalitetnu suradnju s učiteljem $(M=2,57, s=1,207 ; M=2,05$, $\mathrm{s}=1,071 ; \mathrm{M}=2,10, \mathrm{~s}=1,044 ; \mathrm{M}=1.86, \mathrm{~s}=0,854 ; \mathrm{M}=1,67, \mathrm{~s}=1,065 ; \mathrm{M}=1,43$, $\mathrm{s}=0,978$ ), a kod djece čiji roditelji ostvaruju kvalitetnu suradnju s učiteljem češće prevladavaju pozitivne emocije $(\mathrm{M}=3,82, \mathrm{~s}=0,981)$ nego kod djece čiji roditelji ostvaruju osrednje kvalitetnu suradnju s učiteljem $(\mathrm{M}=3,14$, $\mathrm{s}=0,864)$. Kontinuirana i kvalitetna suradnja između učitelja i roditelja je od iznimne važnosti za dobrobit djeteta. Njihovi se odnosi trebaju temeljiti na poštovanju, povjerenju i zajedničkoj odgovornosti jer imaju zajednički ciljoptimalan razvoj djeteta. Suradnja između njih je potrebna zbog praćenja djeteta, otkrivanja potencijalnih problema, poticanja razvoja i što bolje psihosocijalne prilagodbe djeteta na situaciju razvoda njegovih roditelja (Brajša-Žganec i Slaviček, 2014). Osim djeci, potpora od strane učitelja je od velike pomoći i roditeljima (Bujišić, 2005). Rezultati su ovog istraživanja potvrdili ovakve teorijske pretpostavke.

Kada smo u dijelu istraživanja, pitali učitelje za mišljenje o njihovoj ulozi u prilagodbi djece na razvod njihovih roditelja, smatrali su ju veoma važnom. Svoju ulogu smatraju iznimno značajnom. Ono što najčešće navode jeste kako je važno da djeca u njih imaju povjerenja jer će im se, u tom slučaju, uvijek obratiti kada im nešto treba. Nadalje, navode važnost pružanja ljubavi, podrške, razumijevanja, prijateljstva itd. (Potpora, toplina, utjeha, sigurna luka, iskren prijatelj, Djetetu je potrebno pokazati razumijevanje $i$ podršku itd.) Važno je i, kažu, biti dostupan djeci za razgovor. Kvalitetna 
suradnja s roditeljima je nešto što, također, većina njih navodi kao važno kako bi se dijete na razvod prilagodilo na najbolji mogući način. I u široj znanstveno-stručnoj literaturi je naglašena vrlo važna uloga učitelja $u$ prilagodbi djeteta na razvod njegovih roditelja. Vrlo je važno da učitelj djetetu pruži osjećaj stabilnosti, prijateljstva i potpore. Važna je, dakako, i njegova otvorenost za razgovor s djetetom (Bujišić, 2005). Upravo su ove značajke, kao najvažnije, prepoznali i ispitanici u ovom istraživanju. Nadalje, ispitanici su uočili i važnost kvalitetne suradnje s roditeljima, koja je iznimno važna, a njihovi međusobni odnosi trebaju se temeljiti na povjerenju i poštovanju radi što bolje psihosocijalne prilagodbe djeteta (Brajša-Žganec i Slaviček, 2014). Ukoliko je pak prisutna smanjena angažiranost roditelja zbog zaokupljenosti njihovim međusobnim odnosom, učitelj je osoba koja djetetu treba pružiti sigurnost (Čudina Obradović i Obradović, 2006; Janković, 2008).

\section{ZAKLJUČAK}

Veliki broj djece i prije i nakon razvoda braka živi u konfliktnom obiteljskom okruženju, što nesumnjivo ima neželjene posljedice na njihov razvoj, napredovanje i ponašanje. Učitelji razredne nastave koji s djecom provode veliki/značajan dio dana u posebnoj su prilici zapažati ponašanja $i$ promjene $\mathrm{u}$ ponašanju djece. $\mathrm{S}$ ciljem ispitivanja promjena $\mathrm{u}$ nekim aspektima ponašanja djece razvedenih roditelja uzrokovanih razvodom i uloge učitelja razredne nastave $u$ prilagodbi djece na razvod njihovih roditelja, provelo se istraživanje s učiteljima razredne nastave. Nastojalo se ispitati je li razvod roditelja prema mišljenju učitelja kao osoba koje provode veliki dio dana s djecom imao negativne posljedice na razvoj djece, jesu li se dogodile promjene u dječjim emocionalnim reakcijama, eksternaliziranim i 
internaliziranim ponašanjima, školskom uspjehu i ponašanju na nastavi te odnosima s drugima. Osim toga, od učitelja se tražilo mišljenje o važnosti njihove uloge u procesu prilagodbe djeteta na razvod roditelja.

Hipoteza o negativnim posljedicama razvoda roditelja na razvoj djeteta je potvrđena. Naime, 51,3\% ispitanika smatra da je razvod imao negativne posljedice na dijete na koje smo se usmjeravali prilikom istraživanja. Hipoteze, nadalje, o promjenama u dječjim eksternaliziranim ponašanjima te školskom uspjehu i ponašanju na nastavi, nisu potvrđene. Razvod nije utvrđen kao značajan prediktor promjena $\mathrm{u}$, prethodno navedenim, aspektima ponašanja djece razvedenih roditelja. Što se tiče emocionalnog reagiranja, utvrđena je razlika u strahu djece. Djeca su, prema rezultatima, pokazivala statistički značajno više straha prije razvoda nego nakon njega. Ista je situacija i kod internaliziranih ponašanja, točnije kod plašljivosti djece. Što se tiče zapažanja ispitanika o odnosima djece s drugim ljudima, rezultati su pokazali da su se djeca prije razvoda statistički značajno više povlačila od vršnjaka nego nakon razvoda.

Rezultati su djelomično potvrdili hipotezu o životnoj dobi kao prediktoru promjena jedino $\mathrm{u}$ dijelu eksternaliziranih ponašanja djece. Nalazimo da su sedmogodišnjaci statistički značajno skloniji samoozljeđivanju, psihičkoj agresiji prema vršnjacima te uništavanju imovine od osmogodišnjaka, devetogodišnjaka i desetogodišnjaka. Skloniji su i fizičkoj agresiji prema vršnjacima nego devetogodišnjaci. Što se tiče spola, situacija je ista kao i kod životne dobi. Dječaci su skloniji fizičkoj i psihičkoj agresiji prema učitelju/ici, nekim seksualnim ponašanjima koja su neprimjerena dobi te bježanju iz škole od djevojčica. Prisutnost nasilja $u$ obitelji za vrijeme i/ili nakon razvoda pokazalo se kao značajan prediktor 
dijela emocionalnog reagiranja djece i njihovih eksternaliziranih ponašanja. Djeca u čijoj je obitelji bilo prisutno nasilje za vrijeme i/ili nakon razvoda češće izražavaju emocije destruktivnim ponašanjima, primjenjuju fizičku i psihičku agresiju prema vršnjacima, a rizik za razvoj problema u ponašanju je kod njih veći nego kod djece u čijoj obitelji nasilje nije bilo prisutno. Nadalje, što se tiče konfliktne prirode razvoda, dokazana je kao značajan prediktor za dio emocionalnog reagiranja djece. Djeca koja su proživjela visokokonfliktan razvod roditelja pokazuju značajno više ljutnje i bijesa od djece koja ga nisu proživjela kao takvog. Održavanje redovitih kontakata s roditeljem s kojim dijete ne živi pokazalo se značajnim prediktorom za promjene u dijelu emocionalnih reakcija i eksternaliziranih ponašanja djece razvedenih roditelja. Djeca koja nisu u redovitom kontaktu s roditeljem s kojim ne žive pokazuju statistički značajno više negativnih emocija te fizičke i psihičke agresije prema vršnjacima, a kod djece koja su u redovitom kontaktu prevladavaju pozitivne emocije. No, u ovom je dijelu dobiven i jedan neočekivan rezultat. Naime, dokazano je kako djeca koja nisu u redovitom kontaktu s roditeljem s kojim ne žive pokazuju statistički značajno više pozitivnih emocija od one koja jesu. Ovakav je rezultat, osim što je u suprotnosti s ostalim rezultatima ovog dijela istraživanja, u suprotnosti i sa znanstveno-stručnom literaturom i ranije provedenim istraživanjima. Ostaje otvoreno pitanje o razlozima ovakvog rezultata što bi zasigurno moglo biti solidna osnova budućim istraživačkim radovima. Jedna od mogućih pretpostavki je kako se radilo o visokokonfliktnom braku gdje su stresori bili svakodnevni te su imali negativan utjecaj na dijete, a pozitivna promjena je nastala tek nakon prekida (redovitog) kontakta sa roditeljem-izvorom stresa. Kvaliteta suradnje između učitelja i roditelja se, naposljetku, pokazala značajnim prediktorom za dio emocionalnihm reagiranja, eksternaliziranih 
ponašanja te školskog uspjeha i ponašanja na nastavi. Nalazimo kako djeca čiji učitelji ostvaruju «osrednje» kvalitetnu suradnju s roditeljima pokazuju statistički značajno više negativnih emocija, ljutnje i bijesa i fizičke agresije prema vršnjacima nego djeca čiji roditelji ostvaruju kvalitetnu suradnju s roditeljima. Također su nezadovoljniji svojim životom te svoje emocije češće pokazuju plakanjem i destruktivnim ponašanjima. Posljednja hipoteza o važnosti uloge učitelja u prilagodbi djeteta na razvod njegovih roditelja je potvrđena. Učitelji svoju ulogu smatraju iznimno važnom, a ono što ističu kao najvažnije je poštovanje, potpora, razumijevanje, ljubav i prijateljstvo. Kako bi odnos djece i učitelja bio kvalitetan, međusobno povjerenje je, smatraju učitelji, najvažnije. Kvalitetan odnos učitelja i djece pokazuje se općenito posebno važnim u poticanju razvoja i ponašanja djece, a naše istraživanje fokusirano na neke aspekte ponašanja djece razvedenih roditelja samo je jedan od pokazatelja važnosti uloge učitelja. Dakako, uloga učitelja ne ovisi isključivo samo o ličnosti osobe, njegovog obrazovanja, cjeloživotnog usavršavanja već od različitih osobina i faktora o kojima nerijetko ovisi i napredovanje djece bez obzira na vrste i izvore poteškoća. Uloga učitelja posebno je važna i u uspostavljanju suradnje sa roditeljima djece, bez obzira živi li dijete s oba ili s jednim roditeljem. Međutim, ovo je jedan u nas prilično marginalizirani aspekt odgojno-obrazovnih planova i programa (i kurikuluma) pa je realno očekivati da se i na ovom području dogode pozitivne promjene, a posebno fokusirane na mogućnosti različitih aktivnosti osnaživanja obitelji. 


\title{
SOME BEHAVIOR ASPECTS OF CHILDREN OF DIVORCED PARENTS - TEACHERS' OBSERVATIONS
}

\begin{abstract}
Considering the frequency of divorces throughout the European Union and beyond, the aim of the study was to examine some observed changes in the behavior of children of divorced parents, and the importance of the role of primary school teachers in the process of adapting to the family situation. The research was conducted on a sample of primary school teachers from various parts of Croatia (Primorje-Gorski Kotar County, Brod-Posavina County, Koprivnica-Križevci County, City of Zagreb). Data were collected by using a survey questionnaire. The results of teachers' observations showed that parental divorce did not cause changes in children's externalized behavior and school success. However, the changes were observed in some emotional reactions (fear), internalized behaviors (timidity), and relationships with other people (withdrawal). In addition, variables of age, gender, presence of domestic violence during and /or after divorce, conflict divorce, maintaining regular contact with a parent with whom the child did not live, and the quality of parent-teacher cooperation proved to be statistically significant. Establishing a relationship between one parent (with whom the child lived), and a new partner showed to be a significant predictor of a change in some aspects of children's behavior. The results of the research provided a solid basis for further development of structured protocols in monitoring the development of behavior and progress of children at their earlier developmental age, as one of the significant periods in the life of every human being.
\end{abstract}

Key words: parents, divorce, behavior of children, family empowerment 


\section{REFERENCE}

Amato, P. R., \& Sobolewski, J. M. (2001). The effects of divorce and marital discord on adult children's psychological well-Being. American Sociological Review, 66(6), 900-921.

Amato, P. R. (2014). The consequences of divorce for adults and children: An update. Društvena istraživanja, 23(1), 5-24.

Brajša-Žganec, A. (2003). Dijete i obitelj. Jastrebarsko: Naklada Slap.

Brajša-Žganec, A. i Slaviček, M. (2014). Obitelj i škola: utjecaj obiteljskog sustava na funkcioniranje djeteta u školi. U: A. Brajša-Žganec, J. Lopižić, \& Z. Penezić (ur.), Psihološki aspekti suvremene obitelji, braka i partnerstva (str. 149-173). Jastrebarsko: Naklada Slap.

Bujišić, G. (2005). Dijete i kriza. Zagreb: Golden marketing - Tehnička knjiga.

Čavarović-Gabor, B. (2008). Povezanost razvoda braka roditelja i simptoma traume kod djece. Ljetopis socijalnog rada, 15(1), 69-91.

Čudina Obradović, J. i Obradović, M. (2006). Psihologija braka i obitelji. Zagreb: Golden marketing - Tehnička knjiga.

Fagan, P. F., \& Churchill, A. (2012). The effects of divorce on children. Washington: Marriage and Religion Research Institute. Preuzeto 22.2.2019.

https://marri.us/wpcontent/uploads/pubLications/research_papers/EF1 2A22.pdf.

Grozdanić, S. (2000). Jednoroditeljske obitelji prema uzrocima njihova nastanka. Ljetopis socijalnog rada, 7(2), 169-182.

Hajnić, Lj. (2014). Sindrom otuđenja od roditelja. Ljetopis socijalnog rada, 21(1), 169-178.

Janković, J. (2008). Obitelj u fokusu. Zagreb: Etcetera d.o.o.

Kocijan-Hercigonja, D. i Hercigonja-Novković, V. (2009). Djeca, mladi i nasilje u obitelji. Medicus, 18(2), 181-184.

Kruk, E. (2008). Skrbništvo nad djetetom, pristup djetetu i roditeljska odgovornost. Vancouver: The University of British Columbia. Preuzeto 7.7.2019. s http://www.udruga-dijete-razvod.hr/wp- 
content/uploads/Kruk-Edward-Skrbnistvo-nad-djetetom-pristupdjetetu-i-odgovornost-C-2008-web.pdf.

Laklija, M. i sur. (2005). Zaštita najboljeg interesa djeteta u postupku razvod braka roditelja. Ljetopis socijalnog rada, 12(1), 7-38.

Lee, C. M. (2000). Children's reactions to parental separation and divorce. Paediatrics \& Child Health, 5(4), 217-218.

Milas, G. (2005). Istraživačke metode u psihologiji $i$ drugim društvenim znanostima. Jastrebarsko: Naklada Slap.

Osmak-Franjić, D. (2010). Djeca i konfliktni razvodi. Zagreb: Pravobranitelj za djecu. Preuzeto: 16.3.2019. s: http://www.ocbbz.hr/manual/Zbornik_razvodi.pdf\#page $=62$.

Profaca, B. (2010). Učinci izraženog roditeljskog sukoba tijekom razvoda na dijete. U: D. Osmak- Franjić (ur.), Djeca i konfliktni razvodi (str. 7793). Zagreb: Pravobranitelj za djecu.

Rodriguez, N. (2007). Djeca u vrtlogu razvoda. Rijeka: Dušević \& Kršovnik d.o.o.

Smerić Pecigoš, M. (2007). Obitelj nakon razvoda. Dijete, vrtić, obitelj, 13(50), 10-13. 